\title{
Long-term follow-up of DDD pacing mode
}

\author{
Mateusz Ulman ${ }^{1}$, Maciej Dębski², Andrzej Ząbek², Kazimierz Haberka², Jacek Lelakowski ${ }^{2,3}$, Barbara Małecka ${ }^{2,3}$ \\ ${ }^{1}$ Hospice Care for Adults, Medical Centre in Niepolomice, Poland \\ 2Department of Electrocardiology, John Paul II Hospital in Krakow, Poland \\ ${ }^{3}$ Institute of Cardiology, Jagiellonian University Medical College in Krakow, Poland
}

\begin{abstract}
Background and aim: The aim of this study was to determine the long-term survival of DDD pacing and identify the main reasons for its loss.

Methods: The study group consisted of 496 patients in whom a DDD pacing system was implanted between October 1984 and March 2002 and who were followed up until July 2010. The follow-up period was $152.1 \pm 35.5$ months. The patients' mean age at the time of implantation was $59.5 \pm 12.5$ years, and $53.5 \%$ were male; $58 \%$ had sick sinus syndrome (SSS), $26 \%$ had atrioventricular block (AVB), 15\% had both of these indications simultaneously, and $1 \%$ had other indications. The incidence of lead malfunction, progression to chronic atrial fibrillation (AF), and the rate of infective complications was analysed.

Results: During the follow-up, 369 patients remained in DDD mode stimulation. DDD mode survival rate at one, five, ten and 15 years was, respectively, $96 \%, 86 \%, 77 \%$ and $72 \%$. The most common reason for reprogramming out of DDD mode was the development of permanent AF in 65 (13.1\%) patients. The occurrence of chronic AF was associated with a prior history of paroxysmal AF ( $p=0.0001)$, SSS $(p=0.0215)$, and older age at time of implantation $(p=0.0068)$ compared to patients who remained in sinus rhythm. Lead malfunction caused loss of DDD mode pacing in 56 (11.3\%) patients. Atrial leads were damaged in 37 patients, ventricular in 12 patients, and both leads in seven patients. The subclavian vein puncture was correlated with the mechanical damage of the atrial lead $(p=0.02935)$ compared to cephalic vein access. At the moment of complication, the patients with a dysfunctional lead were significantly younger than those who progressed to chronic AF $(p=0.0019)$. Infective complications which caused temporary loss of DDD pacing were observed in six patients: five had pocket infection and one had lead-dependent infective endocarditis.

Conclusions: 1. Effective DDD pacing from the originally implanted system was noted in a high percentage (72\%) of patients in long-term observation (15 years). 2. Progression to permanent AF is the most common reason for loss of DDD pacing; a history of paroxysmal AF and old age are the risk factors. 3. Subclavian vein puncture is associated with a higher rate of atrial lead damage.
\end{abstract}

Key words: sick sinus syndrome, atrioventricular block, DDD pacing, atrial fibrillation, endocardial lead failure

Kardiol Pol 2014; 72, 6: 519-526

\section{INTRODUCTION}

Permanent cardiac pacing has been a recognised treatment of symptomatic bradycardia since the mid $20^{\text {th }}$ century [1]. Initially, pacemakers were able to stimulate a single cardiac cavity, usually the right ventricle, as V00 cardiac pacing and then VVI. Ventricular stimulation with ventricular pacing synchronous with the $\mathrm{P}$ wave, described in 1963, preserved atrioventricular synchrony [2]. Atrioventricular stimulation (DVI, DDD) called physiological appeared at the beginning of the 1980s [3], and the main indications for its implanta- tion have become atrioventricular block (AVB) and sick sinus syndrome (SSS). After implantation of atrioventricular pacemakers, an improvement in quality of life $[4,5]$ and survival of patients has been observed [6]. This improvement was first of all associated with the reduction of pacemaker syndrome [5]. In addition, it has been proved that DDD mode pacing reduces the incidence of permanent atrial fibrillation (permAF) by two-thirds, and the risk of death by one-third, compared to ventricular pacing (VVI) [7]. The DANPACE study [8] revealed the advantage of DDD stimulation over atrial 
stimulation (AAI) in the prevention of AF. Dual chamber pacing is more complicated than single chamber (AAI and $\mathrm{VII}$ ) due to the implantation of two endocardial leads. This prolongs implantation time and evaluation of the device, and requires a more experienced operator [9]. At follow-up of patients treated with DDD pacing, there are clinical situations that force programme pacing to be downgraded, mainly to VVI. Atrial arrhythmias (permAF and atrial flutter) and dysfunction of the endocardial leads are the most common reason for this reprogramming. Durability of DDD pacing system has been assessed in a number of reports. A prospective study compared a follow-up of DDD and VDD stimulation in patients with AVB [10]. In this study, 254 patients received dual-chamber pacemakers, the follow-up lasted on average for 25 months, the DDD mode survival was $89.3 \%$ at the end of the study, and $8.7 \%$ of patients developed permAF. Most studies on the long-term efficacy of DDD pacing are retrospective and come from the early period of implantation history - the 1980s and early 90s. In the cited articles, a follow-up of nearly 3,000 dual-chamber pacemaker patients is described [11-16]. In the follow-up periods ranging from 30 to 44 months, it was necessary to abandon DDD stimulation in $4.3-18 \%$ of cases. The main reason for the loss of DDD pacing mode was the occurrence of permAF and atrial flutter. Gross et al. [14] and Ibrahim et al. [15] showed that DDD pacing mode survival after five years was, respectively, $78 \%$ and $83.5 \%$. In longer follow-up (an average of 81 months), DDD pacing mode survival after five years was 90\%, and after 15 years - 58\% [16]. In a study investigating a Polish population of 295 patients with DDD pacemakers implanted between 1994 and 1997, Majewski et al. [17] reported that after an average of 63 months of follow-up, pacing mode was changed to $\mathrm{VVI}$ in $18 \%$ of patients; in $13 \%$ of patients there occurred permAF, and in $5 \%$ atrial lead damage. Several authors have shown that SSS among the indications $[6,14,17]$ and history of paroxysmal $\mathrm{AF}$ (paroxAF) before implantation [14, 17] are statistically more frequent in patients who developed permAF. Endocardial lead damage in the DDD pacing system in a Polish population of 977 patients was analysed by Małecka et al. [18]. She showed that in a long-term follow-up (mean 59 months), atrial and ventricular lead failure occurred respectively in $8.3 \%$ and $4 \%$ of cases. In that study, the authors attempted to demonstrate the influence of venous access and the construction of leads on the incidence of lead failure [18].

However, there is a lack of sufficiently well-established opinions on the durability of DDD pacing systems, including those implanted since the late $20^{\text {th }}$ century. For that reason, we decided to present our experience.

The aim of this study was the analysis of the occurrence of temporary or permanent loss of primary DDD pacing system in long-term follow-up and the identification of causes of this loss: development of permAF, endocardial lead malfunction and infections.

\section{METHODS}

We reviewed the records of all patients with implanted dual chamber pacemakers $(1,086)$ between October 1984 and March 2002. The necessary condition to enroll the patients to the study was the regularity of their follow-up examinations of at least once a year until July 2010. We decided to assess only the population who were in follow-up at the time of data collection in order to be able to recall the patient to examine them. These criteria were fulfilled by 496 patients. 590 patients were lost to follow-up before 2010; in a few cases they changed their pacemaker centre, but the majority of them died. We chose the period 1984-2002 because it was the initial stage of DDD pacemaker implantation in the centre. Before 2002, only leads with passive fixation were used. Because of centralised purchasing from Biotronik, leads from this provider were utilised in the majority of patients (89\%). The metal wire in atrial leads TIJ 53 UP and DJP 53 UP from Biotronik consisted of three microfilaments, whereas the atrial and ventricular leads consisted of four.

We gathered information for the purpose of this study from electronic database Impuls-BIS by ITAM, and IMPULS. Supplementary information was derived from the records of outpatient clinics and the operative reports. The information reviewed included: 1 . Patient demographics: gender, age at the time of: a) implantation, b) DDD pacing loss; 2. Indication for implantation: a) SSS, b) AVB: $2^{\text {nd }}$ and $3^{\text {rd }}$ degree, c) the occurrence of both of these indications simultaneously $(\mathrm{SSS}+\mathrm{AVB}), \mathrm{d})$ other; 3. Presence or absence of a history of paroxAF before implantation, 4. Lead model (unipolar, bipolar) and the number of microfilaments comprising the lead, 5. Venous access (cephalic venesection, subclavian vein puncture), 6. Duration of follow-up, 7. Reason for loss of the primary DDD pacing mode including development of permAF, lead damage and infection related to pacing system.

We evaluated the incidence and causes of loss of the DDD pacing. The diagnosis of lead malfunction was based on the presence of increased capture threshold, failure to sense, and/or alterations in lead impedance. Mechanical lead damage was confirmed if possible by chest X-ray. PermAF was defined as AF found on two consecutive visits to an outpatient clinic. AF diagnosis was based on the electrocardiogram (ECG) records (leads I and II) stored in the IMPULS database, and printouts of intracardiac electrogram in atrial channel from the pacemaker programmer. About a dozen of the patients were called for additional ECG and chest X-ray examinations. Infection caused both by lead-dependent infective endocarditis and pocket infection led to loss of DDD pacing due to extraction of leads and the devices.

\section{Statistical analysis}

The data was evaluated using Statistica 10. Normality was tested using Shapiro-Wilk test. Mann-Whitney $U$ test was used for non-normal distributions. Kruskal-Wallis test was used to 
compare more than two independent groups of non-normal distribution. Data is presented as mean with standard deviations, additionally in tables as median and interquartile range (IQR). Groups were compared with the $\chi^{2}$ test with one degree of freedom for discrete variables. Event-free rates were calculated with Kaplan-Meier analysis. The first event was counted as an end point in each case. Clinical variables were submitted to multivariate analysis. Predictors of loss of DDD and predictors of lead damage were assessed using a Cox's proportional-hazards model. A p value $<0.05$ was considered significant.

\section{RESULTS}

We analysed the population of 496 patients, whose mean age at the time of implantation was $59.5 \pm 12.5$ years; 265 (53.5\%) patients were male. The 590 patients who were lost to follow-up were significantly older at the time of implantation: $66.0 \pm 30.3$ vs. $59.5 \pm 12.5$ years; $p<0.0001$.

The mean follow-up duration in the analysed population was $152.1 \pm 35.5$ months, ranging from 101 to 302 months. During follow-up, 127 (25.6\%) patients lost primary DDD stimulation. After a month of follow-up, $99 \%$

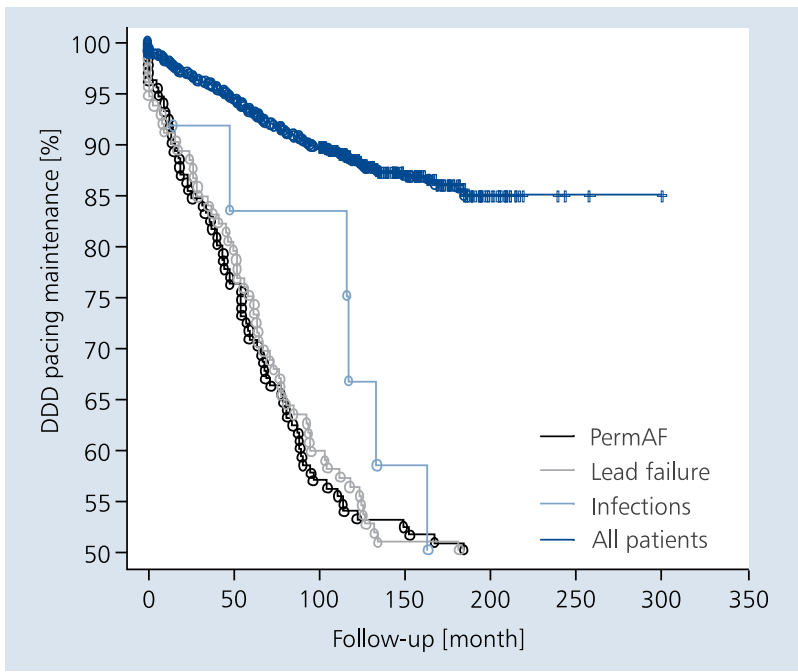

Figure 1. Cumulative maintenance of DDD pacing mode by Kaplan-Meier analysis; PermAF — permanent atrial fibrillation of pacemakers were still in the primary DDD pacing; at six months $97 \%$, at one year $96 \%$, at five years $86 \%$, at ten years $77 \%$ and at 15 years $72 \%$. The curves showing the loss of DDD due to the development of permAF and lead failure did not differ significantly (Fig. 1). Indications for pacemaker implantation are presented in Table 1.

\section{Analysis of group of patients who developed permanent $A F$}

The most common reason for downgrading from DDD to $\mathrm{VVI}$ mode was the permAF development noted in 65 (13.1\%) patients, after an average of $58.9 \pm 43.4$ months of stimulation. PermAF occurred in 46 patients with SSS after an average of $58.3 \pm 44.1$ months, in nine patients with AVB after an average of $55.1 \pm 43.7$ months, and in ten patients with SSS and AVB after an average of $63.2 \pm 44.2$ months of stimulation. Indications for pacemaker implantation had no influence on time to progression to permAF (Kruskal-Wallis test $=0.1827$, $\mathrm{p}=0.9127$ ). All patients remained in VVI mode pacing until the end of follow-up. The group of patients who developed permAF was compared to the rest of the patients (Table 2). There was a substantially greater prevalence of history of paroxAF ( $\left.p=0.0001, \chi^{2}=23.2654\right)$, SSS $(p=0.0215$, $\left.\chi^{2}=5.2858\right)$ and older age $(p=0.0068, U=11093.5)$ at the time of implantation in the group that developed permAF (Table 2).

\section{Analysis of group of patients with lead failure}

Endocardial lead malfunction caused temporary or permanent absence of DDD pacing in 56 (11.3\%) patients (Fig. 2). In 37 patients ( $66 \%$ of patients with lead failure) atrial leads failed. In the whole study population, atrial leads were implanted through subclavian vein puncture $(79 \%)$ or venesection of cephalic vein (21\%). The implantation technique significantly affected the risk of atrial lead failure. Subclavian vein puncture led to lead failure more often than a cephalic vein approach $\left(p=0.02935, \chi^{2}=4.747233\right)$. Ventricular lead damage was observed in 12 patients (21\% of patients with lead failure). In the whole study population, ventricular leads were implanted through subclavian vein puncture (34\%) and venesection of cephalic vein (66\%). The influence of implantation technique on the frequency of ventricular lead failure was

Table 1. Indications for DDD pacing

\begin{tabular}{|lccccc|}
\hline Indications for the implantation & SSS & SSS and AVB & AVB & Others & All patients \\
\hline Number of patients & $287(58 \%)$ & $74(15 \%)$ & $127(26 \%)$ & $8(1 \%)$ & $496(100 \%)$ \\
Age at the time of implantation & $60.7 \pm 11.5$ & $60.9 \pm 12.1$ & $56.6 \pm 14.2$ & $52.5 \pm 13.0$ & $59.5 \pm 12.5$ \\
(median, IQR) [years] & $(62.9 ; 16.3)$ & $(63.9 ; 18.8)$ & $(60.2 ; 21.1)$ & $(49.4 ; 17.4)$ & $(62.5 ; 18.3)$ \\
Number of patients with PAF & 51 & 10 & 10 & 0 & 71 \\
\hline
\end{tabular}

SSS — sick sinus syndrome; AVB — atrioventricular block; IQR — interquartile range; PAF — paroxysmal atrial fibrillation 
Table 2. Comparison of the group of patients who progressed to permanent atrial fibrillation - group 1 - to the rest of the patients - group 2

\begin{tabular}{|c|c|c|c|c|}
\hline & $\begin{array}{c}\text { Group 1: patients } \\
\text { with permanent } A F(n=65)\end{array}$ & $\begin{array}{l}\text { Group 2: patients without } \\
\text { permanent AF }(n=431)\end{array}$ & Test result & $\mathbf{P}$ \\
\hline Sick sinus syndrome & $55(85 \%)$ & $306(71 \%)$ & $5.2858\left(\chi^{2}\right)$ & 0.0215 \\
\hline Paroxysmal AF & $22(34 \%)$ & $49(11 \%)$ & $23.2654\left(\chi^{2}\right)$ & 0.0001 \\
\hline Age at time of implantation & $63.7 \pm 9.1$ & $58.9 \pm 12.8$ & $11,093.5(U)$ & 0.0068 \\
\hline (median, IQR) [years] & $(56.6 ; 11.3)$ & $(61.7 ; 19.4)$ & & \\
\hline Men & $34(52 \%)$ & $232(54 \%)$ & $0.0525\left(\chi^{2}\right)$ & 0.8187 \\
\hline
\end{tabular}

AF — atrial fibrillation; IQR - interquartile range; $U$ - Mann-Whitney $U$ test, $\chi^{2}-$ Chi square test

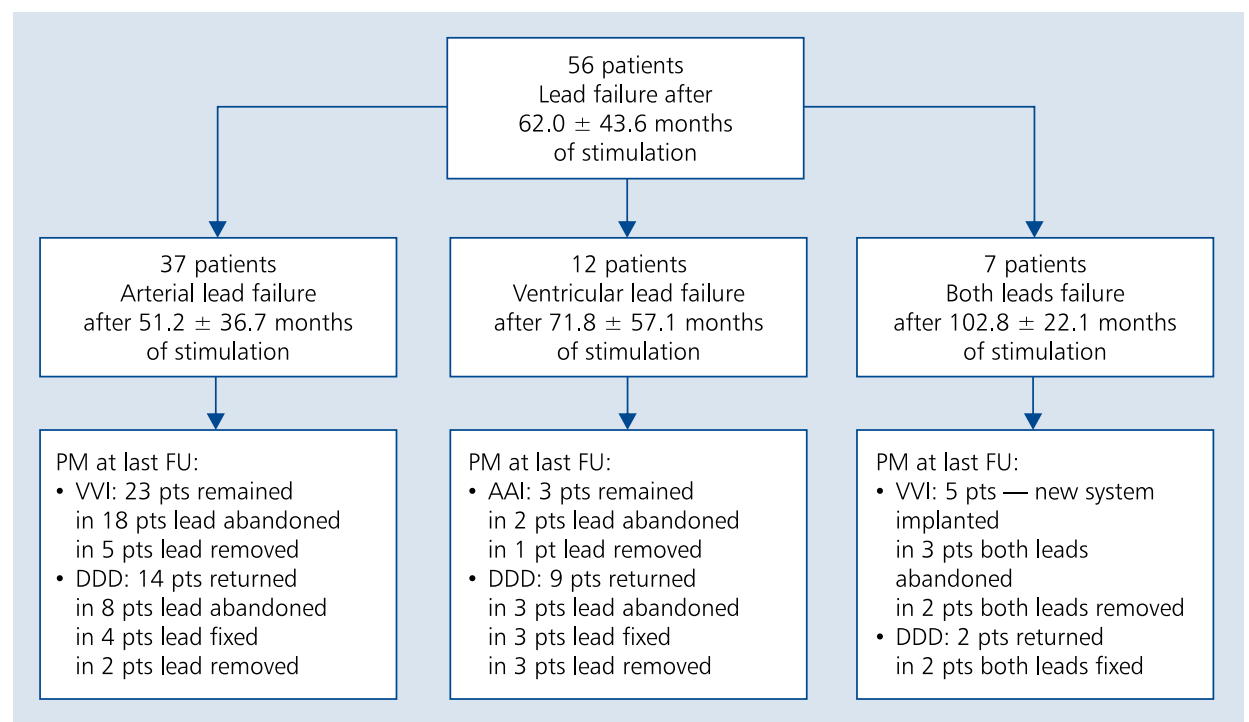

Figure 2. Pacing mode changes of patients with lead failure; FU — follow-up; PM — pacemaker; pts — patients

of borderline statistical significance. Subclavian vein puncture led to lead failure more often than a cephalic vein approach $\left(p=0.05034, \chi^{2}=3.830233\right)$. Malfunction of both leads was demonstrated in seven patients ( $13 \%$ of patients with lead failure). In these patients, it could not be determined which had happened earlier - atrial or ventricular lead damage.

In addition, we conducted an analysis of the impact of lead metal wire structure on lead damage. Three-microfilament leads (4.4\% of Biotronik leads) were implanted in 39 patients: 11 by venesection of cephalic vein, and 28 through subclavian vein puncture. It was found that the subclavian vein puncture increased the incidence of three-microfilament lead failure, compared to four-microfilament leads ( $p=0.00002$, $\left.\chi^{2}=18.28216\right)$. The cephalic approach did not influence the rate of failure (three- vs. four-microfilaments; $p=0.62634$, $\left.\chi^{2}=0.2370526\right)$. In multivariate analysis, only the implantation of a three-microfilament lead was associated with an increased risk of lead damage (hazard ratio $[\mathrm{HR}]=2.20$; confidence interval $[\mathrm{Cl}]$ 1.10-4.39, $\mathrm{p}=0.0259$ ) (Table 3).

\section{Comparison of patients with progression \\ to permanent AF to patients with lead failure}

We observed that the patient's age at the moment of primary DDD pacing loss had a statistically significant association with the cause of this loss - younger patients $(61.5 \pm 15.1$ years $)$ more frequently had lead malfunction, while in older patients (70.0 \pm 9.7 years), the loss of DDD pacing was mainly due to the development of permAF $(U=1243.0, p=0.0019)$. ParoxAF before pacemaker implantation $(p=0.0026$; $\left.\chi^{2}=9.0689\right)$ and SSS indication $\left(p=0.0194 ; \chi^{2}=5.4651\right)$ occurred significantly more often in patients who progressed to permAF. AVB indication was present significantly more often in the group with lead damage $\left(p=0.0159, \chi^{2}=5.8139\right)$. It was also observed that the gender and duration of stimulation had no statistically significant correlation with the cause of DDD pacing loss (Table 4).

Infections related to pacing system were identified in six $(1.2 \%)$ patients: five had a pocket infection and one had a lead-dependent infective endocarditis. In all of these pa- 
Table 3. Multivariate analysis of risk factors for lead damage in the group of Biotronik leads ( $89 \%$ of leads in assessed population)

\begin{tabular}{|c|c|c|c|}
\hline Parameter & Hazard ratio & $95 \%$ confidence interval & $\mathbf{P}$ \\
\hline Three-microfilament lead & 2.20 & $1.10-4.39$ & 0.0259 \\
\hline Subclavian access & 1.15 & $0.76-1.75$ & 0.5145 \\
\hline
\end{tabular}

Table 4. Comparison of patients who progressed to permanent atrial fibrillation (AF) to patients with lead failure

\begin{tabular}{|lcccc|} 
Reason for loss of DDD stimulation & Lead failure & Permanent AF & Test result & P \\
\hline Number of the patients & 56 & 65 & - & - \\
Men & $51.8 \%$ & $50.8 \%$ & $0.0124\left(\chi^{2}\right)$ & 0.9112 \\
Age at the time of loss of stimulation & $61.5 \pm 15.1$ & $70.0 \pm 9.7$ & $1,243.0(\mathrm{U})$ & 0.0019 \\
(median, IQR) [years] & $(63.9 ; 23.3)$ & $(72.2 ; 9.4)$ & & 0.5307 \\
Duration of stimulation & $62.0 \pm 43.6$ & $57.6 \pm 43.7$ & $1,725.5(\mathrm{U})$ & \\
(median, IQR) [months] & $(61.3 ; 66.7)$ & $(55.4 ; 65.9)$ & & 0.0194 \\
Indications [number of patients]: & & & & \\
$\quad$ Sick sinus syndrome (SSS) & 28 & 46 & $5.4651\left(\chi^{2}\right)$ & 0.0159 \\
$\quad$ Atrioventricular block (AVB) & 18 & 9 & $0.1333\left(\chi^{2}\right)$ & 0.7150 \\
SSS + AVB & 10 & 22 & $9.0689\left(\chi^{2}\right)$ & 0.0026 \\
History of paroxysmal AF [number of patients] & 6 & 10 & \\
\hline
\end{tabular}

IQR — interquartile range; $U$ - Mann-Whitney $U$ test, $\chi^{2}$ - Chi square test

Table 5. Multivariate analysis of risk factors for loss of DDD stimulation

\begin{tabular}{|lccc|}
\hline Parameter & Hazard ratio & 95\% confidence interval & P \\
\hline Age at the time of implantation & 1.00 & $0.99-1.02$ & 0.9806 \\
Female & 1.00 & $0.70-1.42$ & 0.9888 \\
Sick sinus syndrome at implantation & 1.38 & $0.81-2.32$ & 0.2339 \\
Atrioventricular block at implantation & 1.26 & $0.80-1.97$ & 0.3227 \\
Paroxysmal atrial fibrillation prior to implantation & 2.09 & $1.37-3.18$ & 0.0006 \\
Subclavian access of atrial lead & 1.05 & $0.67-1.64$ & 0.8276 \\
Subclavian access of ventricular lead & 0.93 & $0.63-1.37$ & 0.7132 \\
\hline
\end{tabular}

tients, the whole system was removed. In four patients, the new DDD pacing system was implanted at the contralateral side of the chest, in one a VVI system was implanted, and in one patient there was no further indication to pacing therapy. Surgical site infection occurred in two cases after first implantation (an incidence rate of 0.5/1000 pacemaker-year) and in four cases after replacement (1.4/1000 pacemaker-year).

In multivariate analysis, paroxAF remained the only significant factor for DDD loss $(\mathrm{HR}=2.09$; $\mathrm{Cl} 1.37-3.18$; $\mathrm{p}=0.0006$ ) (Table 5). In the group of 127 patients who lost the primary DDD pacing system, 65 patients lost it due to permAF, 56 patients lost it due to lead failure, and six due to infective complications. In 29 cases, DDD pacing was reconstructed.

\section{DISCUSSION}

This study describes the clinical outcome of a large group of patients who underwent DDD pacemaker implanta- tion between 1984 and 2002 and remained in long-term follow-up until 2010. The rest of the older patients who received DDD pacemakers in this period at some point were lost to follow-up. This was caused by the consequences of ageing which are senility and death, and in a minority of cases by a change of place of residence, and thus change of pacemaker centre. The mean follow-up duration in this study was $152.1 \pm 35.5$ months, which is the longest time of observation of DDD pacemakers among the studies cited in the references. We observed the loss of primary DDD pacing system in $25.6 \%$ of patients. Though this value is higher than in other studies, in equally long durations of follow-up our percentage of the loss of DDD is the same or even lower. A five-year cumulative rate of DDD pacing survival was $87 \%$, whereas in other studies it was 78-90\% [14-16].

The most common reason for the loss of DDD pacing was permAF development, occurring in $13.1 \%$ of the patients. Pre- 
vious reports have also found that permAF is the most common reason for mode change. It has ranged from $9 \%$ to $13 \%$ of study populations [13-15, 17]. In prospective studies, in which the patients were not lost to follow-up, the incidence of AF was slightly higher (11-17\%) [4, 8, 10]. Patients who developed permAF were older and had more frequently a history of paroxAF compared to those who remained in sinus rhythm. This is consistent with the data from earlier reports $[14,17]$. Several studies have shown a statistically significant association between SSS and the development of AF [6, 14, $17,19]$. In our study, we obtained similar results. It must be noted that the majority of patients with SSS (85\%) and a history of preoperative $\mathrm{AF}(69 \%)$ remained in sinus rhythm until the end of follow-up. This means that DDD pacing enables pharmacotherapy of arrhythmias which has proved to be efficient in long-term follow-up.

Lead failure is one of the most important complications during long-term follow-up after DDD pacemaker implantation. Within our population, lead failure was observed in $11.3 \%$ of the patients. The incidence of lead malfunction has been variously reported in the literature as $10.7 \%$ after 26 months [10], 15.5\% after 30 months [13], 4.3\% after 40.4 months [12], $16.5 \%$ after 60 months [15], 5.1\% after 67.6 months [17], 5\% after 81 months [16] and $22.8 \%$ after 91 months [20]. In our study, lead damage occurred more frequently to atrial leads (66\% of malfunction cases) after a mean follow-up of 51 months. Most authors have reported similarly [12, 13, 15, 17], although two studies have shown that malfunction of ventricular leads was observed more frequently than of atrial leads [20, 21]. Within our population, younger patients more often had verified lead failure, which is consistent with the results of Helguera et al. [21]. In our study, performing the subclavian puncture was associated with more structural damage to endocardial leads. Similar results have been demonstrated by numerous authors [22-26]. It must be mentioned that the influence of type of venous access on lead mechanical damage is evident in leads with a weaker structure (conductor consisting of three microfilaments), which might be attributable to crush syndrome [18]. We emphasise the small number of infective complications, much lower than in a prospective Danish study [27]. The probable reason for this phenomenon is a small team of experienced operators who observe strict standards of asepsis.

\section{Limitations of the study}

Our study is limited by its retrospective nature. Due to selection criteria, we assessed only the population who were alive at the time of data collection. This might have had a considerable impact on the results. Not all risk factors for the development of AF were routinely recorded. The effects of drug therapy and other patient factors on DDD function could not be determined from the database. Despite these limitations, the large number of patients and the long duration of follow-up all validate our data and make it applicable to the general dual chamber pacemaker population.

\section{CONCLUSIONS}

1. After long follow-up (15 years), DDD pacing was maintained in a high rate of patients (72\%) with originally implanted DDD systems.

2. The major reason for abandoning DDD mode was the development of permAF.

3. History of paroxAF increases the risk of DDD mode loss.

4. Atrial leads implanted through subclavian vein puncture failed significantly more often than leads implanted by venesection of cephalic vein.

5. The implantation of three-microfilament leads is a risk factor for lead damage.

\section{Conflict of interest: none declared}

\section{References}

1. Zoll PM. Resuscitation of the heart in ventricular standstill by external electric stimulation. N Engl J Med, 1952; 247: 768-771.

2. Nathan DA, Center S, Wu CY, Keller W. An implantable synchronous pacemaker for the long term correction of complete heart block. Am J Cardiol, 1963; 11: 362-367.

3. Patent US4378020. 1981.

4. Lamas GA, Orav EJ, Stambler BS et al. Quality of life and clinical outcomes in elderly patients treated with ventricular pacing as compared with dual-chamber pacing. N Engl J Med, 1998; 338: 1097-1104.

5. Sulke N, Dritsas A, Bostock J et al. 'Subclinical' pacemaker syndrome: a randomize study of symptom free patients with ventricular demand (VVI) pacemakers upgraded to dual chamber devices. Br Heart J, 1992; 67: 57-64.

6. Hesselson AB, Parsonnet V, Bernstein AD, Bonavita GJ. Deleterious effects of long-term single-chamber ventricular pacing in patients with sick sinus syndrome: the hidden benefits of dual-chamber pacing. J Am Coll Cardiol, 1992; 19: 1542-1549.

7. Connolly SJ, Kerr C, Gent M, Yusuf S. Dual-chamber versus ventricular pacing. Critical Appraisal of Current Data. Circulation, 1996; 94: 578-583.

8. Nielsen JC, Thomsen PEB, Hojberg S et al. A comparison of single-lead atrial pacing with dual-chamber pacing in sick sinus syndrome. DANPACE study. Eur Heart J, 2011; 32: 686-696.

9. Eberhardt E, Bode F, Bonnemeier $\mathrm{H}$ et al. Long term complications in single and dual chamber pacing are influenced by surgical experience and patient morbidity. Heart, 2005; 91: 500-506.

10. Marchandise S, Scavee C, le Polain de Waroux JB et al. Long-term follow-up of DDD and VDD pacing: a prospective non-randomized single-centre comparison of patients with symptomatic atrioventricular block. Europace, 2012; 14: 496-501.

11. Byrd CL, Schwartz SJ, Gonzales M et al. DDD pacemakers maximize hemodynamic benefits and minimize complications for most patients. Pacing Clin Electrophysiol, 1988; 11 (11 Part 2): 1911-1916.

12. Chamberlain-Webber R, Petersen ME, Ingram A et al. Reasons for reprogramming dual chamber pacemakers to VVI mode: a retrospective review using a computer database. Pacing Clin Electrophysiol, 1994; 17 (11 Part 1): 1730-1736.

13. Detollenaere M, van Wassenhove E, Jordaens L. Atrial arrhythmias in dual chamber pacing and their influence on long-term mortality. Pacing Clin Electrophysiol, 1992; 15 (11 Part 2): 1846-1850.

14. Gross JN, Moser S, Benedek ZM et al. DDD pacing mode survival in patients with a dual chamber pacemaker. J Am Coll Cardiol, 1992; 19: 1536-1541. 
15. Ibrahim B, Sanderson JE, Wright B, Palmer R. Dual chamber pacing: how many patients remain in DDD mode over the long term? Br Heart J, 1995; 74: 76-79.

16. Martinelli M, de Arruda Melo S, Nishioka SAD et al. Atrioventricular pacemaker. Incidence and causes of reprogramming in long-term follow-up. Arq Bras Cardiol, 2001; 76: 11-14.

17. Majewski J, Lelakowski J, Haberka K, Tomala I. Trwałość stymulacji dwujamowej w długotrwałej obserwacji. Folia Cardiol, 2002; 9: 567-572.

18. Małecka B, Lelakowski J, Szczepkowski J et al. Niepowodzenia przewlekłej stymulacji serca typu DDD związane z dysfunkcją elektrody: obserwacja własna. Folia Cardiol, 2004; 11: 177-187.

19. Saccomanno G, Marini M, Amadio L, Paciaroni E. Permanent cardiac pacing and thromboembolic risk in elderly patients. Arch Gerontol Geriatr, 1995; 20: 29-36.

20. Masumoto H, Uedaa Y, Katob R, Usuia A. Long-term clinical performance of AAI pacing in patients with sick sinus syndrome: a comparison with dual-chamber pacing. Europace, 2004; 6: 444-450.
21. Helguera ME, Maloney JD, Pinski SL et al. Long-term performance of endocardial pacing leads. PACE, 1994; 17: 56-64.

22. Bonavita G, Perry G, Hesselson AB, Parsonnet V. Incidence of pacemaker lead fracture by location and lead type. PACE, 1990; 13: 551.

23. Parsonnet V, Roelke M. The cephalic vein cutdown versus subclavian puncture for pacemaker/ICD lead implantation. PACE, 1999; 22: 695-697.

24. Roelke M, O’Nunain SS, Osswald S et al. Subclavian crush syndrome complicating transvenous cardioverter defibrillator systems. PACE, 1995; 18: 973-979.

25. Stokes K, McVenes R. Pacing lead fracture. A previously unknown complication of subclavian stick. PACE, 1988; 11: 855.

26. Birnie DH, Parkash R, Exner DV et al. Clinical predictors of fidelis lead failure. Report from the Canadian Heart Rhythm Society Device Committee. Circulation, 2012; 125: 1217-1225.

27. Johansen JB, Jørgensen OD, Møller M et al. Infection after pacemaker implantation: infection rates and risk factors associated with infection in a population-based cohort study of 46299 consecutive patients. Eur Heart J, 2011; 32: 991-998.

\title{
Trwałość stymulacji DDD w obserwacji odległej
}

\author{
Mateusz Ulman'1, Maciej Dębski², Andrzej Ząbek², Kazimierz Haberka², Jacek Lelakowskii ${ }^{2,3}$, Barbara Małecka ${ }^{2,3}$ \\ ${ }^{1}$ Hospicjum Domowe dla Dorosłych, NZOZ Niepołomickie Centrum Profilaktyczno-Lecznicze, Niepołomice \\ ${ }^{2}$ Oddział Kliniczny Elektrokardiologii, KSS im. Jana Pawła II, Kraków \\ ${ }^{3}$ Instytut Kardiologii, Uniwersytet Jagielloński, Collegium Medicum, Kraków
}

\section{Streszczen ie}

Wstęp: Stymulacja DDD jest uznanym sposobem leczenia bloku przedsionkowo-komorowego (AVB) i zespołu chorego węzła zatokowego (SSS). W trakcie obserwacji chorych leczonych stymulacją DDD pojawiają się sytuacje kliniczne, które zmuszają do przeprogramowania rozrusznika do innego trybu, głównie VVI.

Cel: Celem pracy były ocena trwałości stymulacji DDD w długoletniej obserwacji i analiza przyczyn jej utraty.

Metody: Do badania zakwalifikowano dokumentację 496 pacjentów z układami DDD implantowanymi w latach 1984-2002, pozostających do 2010 r. w kontroli poradni przyklinicznej. Średni czas obserwacji wyniósł 152,1 \pm 35,5 miesiąca (8-25 lat). We wszczepionych układach stymulujących korzystano w $89 \%$ z elektrod firmy Biotronik. Wskazania do stymulacji podzielono na: SSS (58\% pacjentów), AVB (26\%), występowanie obu tych wskazań jednocześnie (15\%) oraz inne wskazania (1\%). Średni wiek pacjentów w czasie implantacji wynosił 59,5 \pm 12,5 roku; było 265 (53,5\%) mężczyzn. Oceniano częstość występowania uszkodzeń elektrod endokawitarnych, częstość progresji do utrwalonego migotania przedsionków (AF), a także powikłań infekcyjnych.

Wyniki: Na koniec czasu obserwacji 369 osób pozostało w stymulacji DDD, odpowiednio po 1, 5, 10 i 15 latach — 96\%, 86\%, 77\% i 72\%. Najczęstszą przyczyną utraty była progresja do utrwalonego AF — u 65 (13,1\%) osób, skutkująca zmianą stymulacji do trybu VVI u wszystkich pacjentów z utrwalonym AF. W grupie, w której pojawiło się utrwalone AF, w porównaniu z grupą z rytmem zatokowym, istotnie statystycznie częściej w wywiadzie zanotowano napadowe AF ( $p=0,0001), \operatorname{SSS}(p=0,0215)$ i starszy wiek w momencie implantacji $(p=0,0068)$. Uszkodzenia elektrod endokawitarnych spowodowały utratę stymulacji dwujamowej u 56 (11,3\%) pacjentów. Elektrody przedsionkowe uległy uszkodzeniu u 37 osób. Elektrody przedsionkowe były implantowane poprzez punkcję żyły podobojczykowej w 79\% oraz poprzez wenesekcję żyły odpromieniowej w $21 \%$

\section{Adres do korespondencji:}

lek. Maciej Dębski, Oddział Kliniczny Elektrokardiologii, KSS im. Jana Pawła II, ul. Prądnicka 80, 31-202 Kraków, e-mail: maciekdebski@gmail.com Praca wpłynęła: 05.07.2013 r. 
przypadków. Implantacja metodą punkcji żyły podobojczykowej zwiększała częstość uszkodzeń elektrod przedsionkowych w porównaniu z wenesekcją żyły odpromieniowej ( $p=0,02935)$. Elektrody komorowe uległy uszkodzeniu u 12 pacjentów; były one implantowane poprzez punkcję żyły podobojczykowej w 34\% oraz poprzez wenesekcję żyły odpromieniowej w $66 \%$ przypadkach. Wykazano, że implantacja metodą punkcji żyły podobojczykowej może zwiększać częstość uszkodzeń elektrod komorowych w porównaniu z wenesekcją żyły odpromieniowej ( $p=0,05034)$. Obie elektrody uległy uszkodzeniu u 7 osób. Producent elektrod Biotronik udostępnił dane na temat ich budowy. Część elektrod przedsionkowych, tj. TIJ 53 UP i DJP 53 UP, była zbudowana z 3 mikrofilamentów, natomiast pozostałe elektrody przedsionkowe i elektrody komorowe z 4 mikrofilamentów. Częstość złamań metalowych przewodów elektrod zbudowanych z 3 mikrofilamentów implantowanych metodą punkcji żyły podobojczykowej była większa niż elektrod zbudowanych z 4 mikrofilamentów $(p=0,00002)$. Wśród elektrod implantowanych metodą wenesekcji żyły odpromieniowej nie zaobserwowano podobnej zależności. Wiek pacjentów w momencie utraty stymulacji typu DDD różnił się istotnie statystycznie u chorych z uszkodzeniami i progresją do utrwalonego AF. Uszkodzenia elektrod endokawitarnych częściej występowały u młodszych pacjentów, natomiast fakt rozwinięcia się utrwalonego AF zanotowano u starszych pacjentów ( $p=0,0019$ ). Płeć i czas trwania stymulacji nie miały istotnego statystycznie związku z przyczyną utraty stymulacji DDD. Powikłania infekcyjne pod postacią infekcji loży stymulatora zaobserwowano u 5 osób, a odelektrodowego zapalenia wsierdzia - u 1 chorego.

Wnioski: Wysoki odsetek pacjentów pozostał w trybie stymulacji DDD; 86\% po 5 latach, 77\% po 10 latach i $72 \%$ po 15 latach obserwacji. Najczęstszą przyczyną utraty stymulacji DDD była progresja do utrwalonego AF. Historia napadowego AF przed implantacją, SSS i starszy wiek w momencie implantacji okazały się czynnikami ryzyka progresji do utrwalonego AF. Średni wiek chorych z utrwalonym AF był istotnie wyższy od wieku pacjentów, u których stwierdzono uszkodzenie elektrody endokawitarnej. Implantacja elektrody metodą nakłucia żyły podobojczykowej korelowała z większym ryzykiem uszkodzenia elektrody. W przypadku elektrod implantowanych poprzez nakłucie żyły podobojczykowej konstrukcja metalowego przewodu elektrody wpływała na ich trwałość; 4-mikrofilamentowe elektrody okazały się trwalsze od 3-mikrofilamentowych.

Słowa kluczowe: zespół chorego węzła zatokowego, blok przedsionkowo-komorowy, rozrusznik serca typu DDD, migotanie przedsionków, uszkodzenia elektrod wewnątrzsercowych

Kardiol Pol 2014; 72, 6: 519-526 